\title{
FOREIGN OWNERSHIP AS A NEGLECTED FACTOR IN REGIONS' SMART SPECIALISATION EXPORTS
}

\author{
Jarosław M. NAZARCZUK (D) 1*, Stanisław UMIŃSKI (D) 2, 3 , \\ Tomasz JURKIEWICZ (D) 4 \\ ${ }^{1}$ Faculty of Economic Sciences, University of Warmia and Mazury in Olsztyn, Olsztyn, Poland \\ ${ }^{2}$ Faculty of Economics, University of Gdańsk, Sopot, Poland \\ ${ }^{3}$ Institute for Development, Sopot, Poland \\ ${ }^{4}$ Faculty of Management, University of Gdańsk, Sopot, Poland
}

Received 11 February 2019; accepted 09 March 2020

\begin{abstract}
A region can internationalise in various ways. The question is what type of internationalisation at regional level can be regarded as "smart" and what role should be played in it by foreign owned entities (FOEs)? The paper aims at identifying the role played by FOEs in NUTS-2 smart specialisations' (SS's) internationalisation through exports. With the use of a set of PCSE regressions, the paper depicts the role of FOEs in creating SS-compliant exports against the background of their influence on total regional exports. The obtained results proved the positive role of FOEs in regional exports per se and SS-compliant exports. Yet, FOEs differed substantially, as compared to indigenous entities, in terms of product/regional specialisation and technological advancement. The findings imply the importance of FOEs' embeddedness in regions' economies and possibility of their incorporation in creating or enhancing regional comparative advantages. The paper contributes by: (i) providing empirical verification of one of the aspects of SS strategy which is exports and establishing comprehensive insight into the evaluation of SS, (ii) depicting the role of FOEs in generating SS-compliant exports, (iii) proposing a set of measures to be used in the extended empirical evaluation of SS consequences in the sphere of exports.
\end{abstract}

Keywords: smart specialisation, regional trade, export, export intensity, evaluation, trade, FDI, S3.

JEL Classification: O30, R58, R11, F14, O25.

\section{Introduction}

Whereas smart specialisation (SS) strategy has become a foundation of regional development policy in the EU, empirical evidence on its implications is scarce. In particular, little is known on the nexus between SS and exports. Relation between FDI and exports is hard to be predicted (Estrin et al., 2008; Iammarino \& McCann, 2013). It makes the identification

\footnotetext{
${ }^{\star}$ Corresponding author. E-mail: jaroslaw.nazarczuk@uwm.edu.pl
} 
of the influence of foreign ownership (FO) on SS compliant exports an interesting issue. In the study, the role of FOEs in generating foreign trade turnover, falling into regions' SS, is verified. Foreign trade is considered as a platform for transferring the implications of the globalisation process to regional economies (Coulombe, 2007). It also verifies competitiveness (Krammer, 2017). The aim of the research is to verify: (i) the character, extent to which FOEs contribute to regional SSs, (ii) the role of FOEs in emerging new product specialisations in exports, (iii) the FOEs contribution to regions' exporting comparative advantages.

For the above analysis, the data for Poland's NUTS 2 regions have been chosen, the primary reason being the possibility to distinguish FOEs vs non-FOEs in exporting activity. Such detailed data is unavailable for other countries. The time span is 2004-2015, which covers Poland's entrance to the EU, the global financial and economic crisis of 2008 and recovery after it. Moreover, Poland is a relevant case, because the country has absorbed substantial structural funds, FOEs have heavily contributed to its economic development as well as to foreign trade boosting.

Using a set of panel-corrected standard error (PCSE) regressions, the authors depict the role of FOEs in: (i) total regional exports and in (ii) regional exports compliant with SS. The established approach identifies implications from the operation of SS on regional economies in the area of foreign trade.

The novelty the paper brings, arises mainly from the empirical verification of exports, which is the main external aspect of SS strategy. So far, similar assessments have been conducted for countries, not for regions. The literature overview has shown that generally research is focused on the internal/domestic aspects of SS schemes (Radosevic \& Ciampi Stancova, 2018). The research fills the gap in the literature, by focusing on the most important internationalisation SS component, which is exports. Firms are part of the global value chains; as SS schemes are aimed at improving regions' competitiveness, it is expected to result in regions' export performance.

The paper's novelty also arises from depicting the role of FOEs in generating SS-compliant exports and establishing more comprehensive insight into the evaluation of SS. Internationalisation is a privilege of the "happy few" firms (Mayer \& Ottaviano, 2008). FOEs are different, compared to the indigenous firms. They are more productive, make use of ownership specific advantages as well are experienced in exporting activity. Their role in SS compliant exports however is hard to be predicted and therefore shall be assessed. The presence of foreign capital as such doesn't automatically guarantee the boost of exports, nevertheless the literature review argues that FOEs usually belong to the "happy few" group. It results from OLI advantages and functions that FOEs play (domination, coordination, networking) (Forsgren, 2008), affecting the margins of exports. FOEs' influence on exports much depends on the character of FDI done in the region and the motives that drive the FOEs activity. The combination of region's characteristics with FOEs ones, gives many idiosyncratic dynamic interactions, described as the geography of globalisation. Even though the role of FOEs in boosting national or global exports has been a subject of affluent research, regional analyses thereof are in statu nascendi. As regards contribution of FOEs to SS-compliant exports, very little is known so far for regions. 
As the internationalisation aspect of SS seems to have been neglected so far, another novelty proposed is a set of measures to be used in the extended empirical evaluation of SS consequences in the sphere of exports, given the difficulties in assessing the effects of SS (Foray, 2019). It includes the following indices: product-specific weighted RCA, HHI and Krugman Specialisation. They were calculated for ca. 1300 product groups, separately for FOEs and non-FOEs exports. Thus, the novelty is not only the set of measures itself, that are relevant and shall be used in the similar studies, but also their usage for export analysis of different groups of firms by ownership category. The novelty also stems from identification of the SS compliant exports which required merging of the data on product exports with regional SS priorities. In comparison to other research, the approach enables using highly disaggregated data for exports by product groups.

The results of the research have shown, that FOEs do contribute positively to regional exports, which enhances regional competitiveness and internationalisation. On average, FOEs contribution in 2015 to regional exports was 52.1 per cent, imports (55.4 per cent), whereas it was significantly smaller in capital formation (21.1 per cent) and employment (8.9 per cent). However, there were important inter-regional differences thereof. In the case of exports, for instance, FOEs' regional contribution ranges from 12.6 per cent to 69.5 per cent. Their positive influence is also noticeable within exports particularly consistent with regional SSs (the mean contribution was 47.7 per cent in 2015). The obtained estimates have acknowledged the above findings, also indicating higher magnitude of influence on total regional exports than SS-compliant exports in the case of FOEs.

Additionally, FO exporters in comparison to indigenous ones, were to a higher extent technologically-advanced, product-concentrated and regionally specialized. Despite, a positive and significant effect of FO on SS-compliant exports, their contribution in this regard is lower than in the case of indigenous exporters. It is the result of their insufficient embeddedness in local/regional economies (Nazarczuk et al., 2019), originating from their own strategies and locational preferences (Dziemianowicz et al., 2018; Nazarczuk \& Krajewska, 2018a, 2018b).

The obtained results provide important policy implications for countries/regions hosting FOEs (or willing to attract them). The research also brings practical benefits, related to promotion of exports, the attraction of FOEs, attaining coherence of regional exports with regional SS. Synchronising the above-mentioned activities makes regional policy far more effective. If one of the priorities of regional policy is exports promotion, then the policy of attracting FOEs shall be more selective. From the point of view of coherence of the regional policy and its effectiveness, promotional actions shall be addressed towards export-oriented foreign direct investors.

The research subscribes to the literature focused on the internationalisation aspects of SS. The focus of attention is on the nexus between the activity of FOEs and region's exports compliant with SS, to provide important policy-oriented implications for regional authorities, and the SS policy itself.

The paper is organised as follows. The next section depicts theoretical foundations of a SS concept, which is succeeded by (i) the description of factors affecting internationalisation of firms, and (ii) identification of differences between indigenous and FO exporters' 
performance and their role in generating total regions' exports. The dataset and empirical approach are delivered in the next section, followed by a description of stylized facts on the role of foreign capital in the economy of Poland. Then, the results of the econometric work are presented. The paper concludes with the discussion of findings and policy implications for SS programmes.

\section{Smart specialisation and trade}

\subsection{The basics of smart specialisation internationalisation}

SS concept dominated the debate on the position of regions in a globalising economy. The concept of SS is a response to the challenges facing regions (McCann \& Ortega-Argilés, 2013). The overview of the SS-related literature shows a wide variety of perspectives from which the idea of SS can be tackled, i.a.: economic (regional) growth, innovation systems, entrepreneurial- or self-discovery of competitive advantages, industrial policy, industrial districts, spatial economics, etc. (Charles et al., 2012; Cordes et al., 2016; McCann \& OrtegaArgilés, 2016).

Within its grounds, SS relates to the idea of improvement of regions' competitiveness through the concentration of public intervention and/or resources in a low number of selected branches in a region (Foray, 2014). SS refer to developmental activities, being complement to recent regional specialisations, but emerging in new domains, basing on the available regional assets and historical capabilities, eventually resulting in a more diversified, innovative and competitive regional output, also in less developed areas (Trippl et al., 2019).

Thus, SS has become the concept underpinning many ways of thinking about region's competitive position. It offers several advantages for regional/cohesion policy making and in searching for its effectiveness. It economises the making of regional policy, given the limited available resources and capabilities. The rationale behind SS is concentration of efforts on selected areas in which a region already has revealed strengths, which reflects specialisation (OECD, 2013).

There is a strong correspondence between SS and the comparative advantages concept of D. Ricardo. As stipulated by P. Krugman, although very often we are tempted to appraise the position of countries in terms of absolute advantages, it is comparative advantage that constitutes the proper framework for competitiveness assessment. The same applies to regions. Linking SS with competitiveness, directs attention to the issue of the relations between regional economics with international economics, or more precisely: between a region and international economy.

SS literature has proliferated and - as already mentioned - there are many perspectives from which the theoretical and empirical research has been done. One of them is the international dimension, which however is neglected in the SS-related literature (Hassink \& Gong, 2019). Radosevic and Ciampi Stancova (2018) treat SS as "probably the largest innovation policy experiment in the world", targeted at moving the regions on the R\&D-related growth path. The authors see little attention paid to internationalisation component of SS, which does not correspond with the strong dependence of regions of the EU new Member States on FDI and being part of the global value chains. 
In the guide to research and innovation strategies for SS (RIS3), Foray et al. (2012) put strong emphasis on the international aspects of SS. The issue of internationalisation is referred to in several ways in the document. The SS shall not be designed and developed in isolation, but outward-oriented (Uyarra et al., 2018). The international component and the European trans-regional dimension of SS is highly recommended as a way of transforming the regional economic system and building of the competitive advantages in a few, globally competitive areas. The benchmarking of regional capabilities shall be made in the international context. A crucial element is the position of a region in global value chains. The so-called blind duplication of specialisation, that overlaps with other regions, shall be omitted. Concentrating too much investment on the areas, in which other regions have the same or similar SS, could end in excessive fragmentation and in inability to generate the "critical mass".

\subsection{Internationalisation for a "happy few"}

As it was shown by Mayer and Ottaviano (2008), internationalisation is done by the "happy few" firms, which stems from the fact that exporting (and undertaking FDI) requires higher productivity (Melitz, 2003; Melitz \& Redding, 2014). Heterogeneity has become the fundamental concept in international economics, which reflects the shift from countries to firms, as trading actors. The region's internationalisation is affected by several margins. The firm's extensive margin is a number of exporters from a region (Felbermayr \& Kohler, 2006); average exports value per exporter is firm's intensive margin. The number of products per each exporter represents product extensive margin, while product intensive margin is the average value of exports of each product per firm. Depending on the character of region's export base, given the complexity of possible margins of exports presented above, the internationalisation can have many faces. According to Mayer and Ottaviano (2008), this is the number of exporters that matters most. This complexity of margins can be translated into the regional context. High openness of a region's economy on the one hand reflects high competitiveness. On the other hand, it makes region's economy vulnerable, which results in labour market instability and thus in volatility of economic growth. If within a region there are few exporters, witnessing high volume of exports, alterations in the business cycle in the global market can affect the economic situation of a region seriously (low extensive margin combined with high intensive margin). Alternatively, if there are many exporting firms, but the exports of each of them is lower (high extensive margin combined with low intensive one), the export base is more dispersed and the overall vulnerability to exports-related risks is lower (especially if there is also a sectoral diversification of exports).

Internationalisation is a priority of regional development policy in Poland. In the EU structural funds operational programmes (Ministry of Infrastructure and Development, 2014a) it is treated as a tool for competitiveness improvements and for raising the awareness of benefits stemming from exporting, addressed towards firm located in the eastern part of Poland, suffering from lower competitiveness. Within "Intelligent Development Operational Programme" (Ministry of Infrastructure and Development, 2014b) the financing is addressed towards the firms with the highest innovative potential, which on the grounds of the M. Melitz heterogeneity theory shall positively contribute to the improved export performance (Umiński, 2016). 


\subsection{The FOEs differ}

An important factor in the internationalisation of a regional economy is FDI. FO increases the likelihood of exports (extensive export margin). The export premium of FOEs has been empirically shown for instance by Ciołek and Brodzicki (2016), Jurkiewicz and Umiński (2016), Nazarczuk and Umiński (2018). In fact, the discussion in literature on the differences between FOEs and indigenous entities (non-FOEs) has been present for a long time (Cieślik, 2016). FOEs very often are parts of multinational corporations, function within international value chains, have superior access to distribution networks and resources. The above exemplified advantages have been thoroughly analysed and described as elements of the OLI paradigm by Dunning and Lundan (2014). They are expected to matter for export performance. Given the advantages possessed by FOEs, their positive impact on exports is expected. It must be admitted however, that the relation between FDI and exports is hard to be predicted. It depends on the combination of OLI advantages, a FOE possesses, with an investor's motivation (searching for markets, resources, efficiency and strategic assets (Behrman, 1972; Iammarino \& McCann, 2013)). The fundamental question asked in the literature is whether FDI and trade are complementary or substitutive (Helpman, 1984; Helpman \& Krugman, 1985; Markusen, 1984). The empirical research shows mixed results, the relation being also dependent on the vertical or horizontal type of FDI (Jensen, 2002; Varblane \& Ziacik, 2000). According to Estrin et al. (2008), export performance of FOEs is difficult to predict because the position of a subsidiary within the structure of MNE shall be taken into account. According to Forsgren (2008), MNEs can be described in a dichotomic way as a "beauty and a beast", which reflects their ambiguous influence on the host country or region's economy. MNEs perform various functions, described by Forsgren (2008), that determine the MNEs impact on trade. They are dominators (possessing market power), coordinators (searching for cost efficiency through internalisation), knowledge creators (and exchangers), networkers and also perform politicizing function. Similar opinion was presented by Glickman and Woodward (1989), who pointed the complex influence of FDI on the U.S. economy, saying that FDI is "neither nemesis decried by economic nationalists, nor the panacea its boosters claim... It brings both good and bad, but crucially it brings a set of challenges to us all” (Glickman \& Woodward, 1989, p. ix). According to Dittfeld (2017) and Nguyen (2017), the relation between multinationality and performance (including internationalisation) is highly contextual. Mudambi et al. (2018) underline the interactive relations between the OLI paradigm components, saying that locational factors change the ownership advantages possessed by a foreign investor. Dunning (2003) and Dunning (2009), while discussing the paradigm pays much attention to the spatial preferences of foreign direct investors. Localisation issues are equally important (to other OLI components) and shall not be neglected, as it was stipulated by Ethier (1986).

Another question is FOEs' technological advancement vs. indigenous entities, that is also reflected in the structure of exports (Nazarczuk et al., 2018). There are several aspects of this advancement. Firstly, it can be checked if FOEs' activity is characterised by more intensive innovative activity ( $R \& D$ in particular). It is often expected to be so, because a foreign entity possesses OLI advantages. In practice, they do not have to translate into the superior position 
of FOEs in this respect, as regards the activity carried by a FOE on the Poland's market. FOE can simply rely on the technological capabilities established in the country of origin or stemming from the sophisticated relations and knowledge generated within subsidiaries of MNE. Thus, in the host country, FOEs do not necessarily have to report an extraordinary intensive innovation activity. This issue has been raised by (Chang et al., 2013), who pointed two conflicting hypotheses regarding foreign subsidiary post-entry performance. In other words, the technological capabilities are brought from abroad by FOE and can constitute the source of competitive advantage. It is interesting to analyse if within SS covered exports, FOEs show superiority vs. non-FOEs as regards technological advancement.

According to Leichenko and Erickson (1997), FOEs are providers of external economies, that positively contribute to regions' attractiveness for other FOEs, as well as increases local, indigenous firms' propensity to export. Aitken, Hanson, and Harrison (1997) for Mexico have identified the positive role of FOEs, influencing the export performance of the nearby indigenous companies through the dissemination of information about foreign markets as well through technology and distribution channels that reduce foreign markets entry costs. Authors have found that probability that an indigenous plant becomes an exporter, in a positive way is correlated with the proximity to a FOE.

The impact of FOEs on region's export performance also depends on the regions' characteristics. Sun (2001) has identified strongest, positive influence of FOEs on coastal Chinese provinces' exports and also positive, but weaker one, for the central ones. For the western region, the influence has been found to be statistically insignificant. The strength of influence is dependent on regions' structural characteristics, such as the level of development, industrial structure and already existing openness to foreign trade. Similar "conditionality", as regards the nexus between regional exports, FDI and economic growth, has been identified for the Chinese regions by Sun and Parikh (2010).

Iammarino and McCann (2013) have provided a thorough interpretation of Hymer's contribution to the understanding of localisation choices. According to Hymer's law of increasing firm size, as the company develops and transforms into the MNE, a pyramidal structure evolves, with three levels of hierarchy. The lowest one is production. The higher one is an intermediary, performing control and coordination. The highest one performs top level management and makes strategic decisions. According to "correspondence principle", the hierarchical structure of multinational enterprise translates into the hierarchy of localisations (Iammarino \& McCann, 2013). The highest level of the hierarchy is located in the global cities. The lowest one remains relatively evenly spread among localisations, reflecting their attractiveness (described by resources offered, like labour, raw materials etc.). The intermediary level is clustered around big cities, providing sufficient communication networks and qualified labour (Hymer, 1972).

Interesting aspects of FOEs activity in regions were shown by Cantwell and Iammarino (2001). The authors conclude, that the activity of FOEs, in the host countries, results in the increased regional inequalities. The "first rank" regions position is improved, while the less attractive (less competitive) regions are marginalised. The activity of MNEs represents chances, that can be utilised by firms from host regions. It is possibility to cooperate and to become a part of international production (or value added) networks. These are regions 
that possess the most advanced technological profiles, that can become part of the technological cooperation networks. Spillover effects stemming from the activity of the FOEs are determined by the character of the host region, its technological position and industrial structure. Processes of technology accumulation by FOEs - propelled by cumulative causation - lead to the increased regional inequalities. Technology accumulation is however limited to the concrete, competitive localisations. This observations by Cantwell and Iammarino (2001) and Iammarino and McCann (2013) prove that FOEs' impact on SS-compliant exports can be ambiguous and conditioned on the regional economy characteristics. Moreover, as shown by Tan and Meyer (2011), country of origin characteristics may also influence the FDI agglomeration patterns. The combination of region's characteristics with FOEs ones, gives many idiosyncratic interactions, that are dynamic in their nature (described as the geography of globalisation by Buckley and Ghauri (2004)).

The two hypotheses have been formulated, with reference to the nature of FDI and the role performed in the host economies by FOEs.

\section{H1: FOEs contribute positively to regions' exports}

The setting of $\mathrm{H} 1$ is justified on the grounds of the OLI advantages possessed by entities with foreign capital. However, as already mentioned, the impact FOEs exert on the host, regional economy, depends on the array of factors, including the combination of advantages within OLI structure with motives driving the activity of particular investor. Moreover, if a FOE is a part of the multinational structure, its functions performed also matter for contribution to region's exports. They determine the margins of exports as well as its structure (also in terms of manufacturing products vs. services), which translates into overall contribution to region's exports. The positive impact of FOEs on region's exports is expected, which stems from their high share in exports of Poland, which is shown in the presented stylised facts.

\section{H2: FOEs exports are compliant with sectoral composition of smart specialisations}

Dependent on investment attractiveness, structural characteristics and the character of FDI, their contribution may vary. The stylised facts depict strong differentiation of regions in this regard. The expected FOEs' positive impact on SS compliant exports stems from the following: (i) regional authorities use several regional-policy instruments aimed at attraction of foreign investors, (ii) an assumption, that internationalisation is on top of regional policy priorities, (iii) investors are attracted by the operation of special economic zones, which represent the instrument addressed at selected investors, that shall positively contribute to regional exports in line with the defined region's SS profile. The above described arguments rest on the assumption that regional policy is effective and comprehensive, the internationalisation component is explicit and in the formulation of SSs, the FOEs activity has been integrated as regards their contribution to exports.

On the other hand, an alternative approach can be taken, in which FOEs are footloose, their activity does not have to fit into regional SSs' complaint exports, they locate according to their OLI advantages and motivations. Moreover, being dominators, FOEs (Forsgren, 2008) can influence the formulation of priorities within SSs. It would however make the correspondence between activity of FOEs and regional development and shall make FOEs' exports compliant with regional SS's exports profile. In fact, this relation raises the question of endogeneity. 
In a nutshell, the issue that will be verified in hypothesis $\mathrm{H} 2$ is weather FOEs play a role of assets creation or diversion, with reference to regional exports profile compliance with SSs.

\section{Dataset and empirical approach}

The study is based on the data from the Customs Chamber on regional (NUTS 2) exports, at 4-digit $\mathrm{CN}$ (ca. 1300) product groups, separated into flows originating from indigenous and FO exporters. The dataset was furtherly combined with the data on regional structural characteristics obtained from QoG EU Regional Dataset (Charron et al., 2016) and Poland's Central Statistical Office. The regions' SSs were obtained from the Eye@RIS3 database in the NACE rev. 2 (2digit) classification, which was translated into $\mathrm{CN}$ product groups, existing in exports. The operation involved careful assignation of each of the $\mathrm{CN}$ product groups to the corresponding NACE rev. 2 economic activity. However, due to rather broadly defined agricultural specialisations in Eye@RIS3 database (ranging for the whole section in NACE), additional controls for sector-specific SS exports, were introduced.

At the initial stage, the importance of FO exporters have been inspected, as compared to the indigenous ones, in the emergence and existence of revealed comparative advantages. By a separate product-specific (for indigenous and FO exporters) calculations of weighted revealed comparative advantages (WRCA) indices, presented in statistical perspective, the origins of the existing advantages falling into regions' SS are shown. The specific characteristics of SSs, including: product concentration, no. of product groups, dissimilarity/similarity to national SS, were validated.

The following empirical procedure was divided into two consecutive steps. Firstly, the positive role of FOEs in stimulating exports is verified, which provides the background to the final analysis, by i.a. verifying the directions and significance of conditioning variables. Secondly, the stimulant contribution of FOEs to exports compliant with SS is counterchecked. The verification of FOEs' influence on regional exports and exports compliant with regional smart specialisations required the introduction of variables depicting: (i) the structural characteristics of regions (human capital, access to the sea and industry share), (ii) the role of FOEs in the regions' economies as well as in SS-compliant exports including its sectoral characteristics (agricultural and high-tech products).

The evaluation of the dataset has resulted in emergence of few issues. Firstly, according to the modified Wald test for groupwise heteroskedasticity, the null hypothesis of homoscedasticity was rejected in favour of heteroskedasticity. The p-value (0.00) of Pesaran's test of cross sectional independence (Pesaran, 2004) indicated an issue of a cross-sectional dependence in the dataset. The rerun CD-test acknowledged the above findings. Wooldridge test for autocorrelation in panel data, together with Baltagi and Li (1995) test for first-order serial correlation, Baltagi and Li (1991) joint test for serial correlation and random effects, have pointed towards an issue of serial correlation and its character.

Since, the analysis faces few data concerns, like heteroscedasticity, serial correlation, cross-sectional dependence, a model that handles properly the above-mentioned issues has been applied. The Panel Corrected Standard Errors (PCSE) estimations, achieved through Prais-Winsten method are robust to heteroscedasticity, serial correlation and different forms 
of cross-sectional or temporal dependency. According to Beck and Katz (1995), this approach generates more consistent results than FGLS estimates.

Dependent variables are the following: (i) logged regional exports (lex), (ii) logged value of regional exports consistent with regional SSs (lsmart_ex). The role of FOEs was introduced in panel regressions in many ways (as a share of employment, ratio of FOE to $1 \mathrm{k}$ registered entities, share of exports, including SS-related), among other factors contributing to SS' compliant exports, to achieve consistent results. Table 1 presents descriptive statistics of the covariates used in econometric regressions, while Table 2 the correlation matrix.

Table 1. Descriptive statistics of covariates used in regressions (source: own elaboration)

\begin{tabular}{|l|l|c|c|c|c|c|c|}
\hline \multicolumn{1}{|c|}{ Variables } & \multicolumn{1}{|c|}{ Description } & Source & N & Mean & SD & Min & Max \\
\hline hc & $\begin{array}{l}\text { Share of population aged 25- } \\
\text { 64y. with tertiary education }\end{array}$ & QoG & 192 & 20.708 & 4.838 & 12.200 & 39.800 \\
\hline sea & Access to sea (dummy) & Map & 192 & 0.125 & 0.332 & 0.000 & 1.000 \\
\hline sh_emp_2 & $\begin{array}{l}\text { Share of industry in } \\
\text { employment }\end{array}$ & CSO & 192 & 30.457 & 5.008 & 19.300 & 40.700 \\
\hline sh_emp_foe & Share of FOEs in employment & CSO & 192 & 0.087 & 0.054 & 0.017 & 0.261 \\
\hline sh_foe_1kent & $\begin{array}{l}\text { No. of FOEs per 1k registered } \\
\text { entities }\end{array}$ & CSO & 192 & 4.685 & 2.696 & 1.081 & 14.541 \\
\hline sh_foe_ex & Share of FOE in exports & CC & 192 & 0.521 & 0.140 & 0.116 & 0.722 \\
\hline sh_foe_smart & $\begin{array}{l}\text { Share of FOE in exports } \\
\text { compliant with regional smart } \\
\text { specialisations }\end{array}$ & CC \& E & 192 & 0.473 & 0.222 & 0.030 & 0.830 \\
\hline $\begin{array}{l}\text { sh_foe_ } \\
\text { smart_agri }\end{array}$ & $\begin{array}{l}\text { Share of FOE in exports } \\
\text { compliant with agricultural } \\
\text { regional smart specialisations }\end{array}$ & CC \& E & 192 & 0.165 & 0.168 & 0.000 & 0.698 \\
\hline $\begin{array}{l}\text { sh_foe_ } \\
\text { smart_ht }\end{array}$ & $\begin{array}{l}\text { Share of FOE in high-tech } \\
\text { exports compliant with } \\
\text { regional smart specialisations }\end{array}$ & CC \& E & 192 & 0.464 & 0.350 & 0.000 & 0.999 \\
\hline
\end{tabular}

Note: CC - Customs Chamber in Poland, CC \& E - combined data from Customs Chamber in Poland and Eye@RIS3 database, CSO - Central Statistical Office in Poland, QoG - Quality of Government Dataset (Charron et al., 2016)

Table 2. Correlation matrix of covariates used in regressions (source: own elaboration)

\begin{tabular}{|l|c|c|c|c|c|c|c|c|}
\hline \multicolumn{1}{|c|}{ Variables } & $(1)$ & $(2)$ & $(3)$ & $(4)$ & $(5)$ & $(6)$ & (7) & (8) \\
\hline (1) sea & 1.000 & & & & & & & \\
\hline (2) sh_emp_2 & 0.019 & 1.000 & & & & & & \\
\hline (3) sh_emp_foe & 0.034 & 0.174 & 1.000 & & & & & \\
\hline (4) hc & 0.029 & -0.247 & 0.446 & 1.000 & & & & \\
\hline (5) sh_foe_1kent & 0.139 & 0.102 & 0.926 & 0.469 & 1.000 & & & \\
\hline (6) sh_foe_ex & -0.195 & 0.594 & 0.504 & -0.086 & 0.398 & 1.000 & & \\
\hline (7) sh_foe_smart & -0.260 & 0.353 & 0.526 & 0.010 & 0.403 & 0.837 & 1.000 & \\
\hline (8) sh_foe_smart_ht & -0.165 & 0.126 & 0.275 & 0.110 & 0.169 & 0.092 & 0.276 & 1.000 \\
\hline
\end{tabular}


Due to limited no. of regions (16) in the study, there is a risk of high correlation among selected variables. The issue concerns especially the role of FOEs. Thus, they are introduced separately into the models to avoid unnecessary multicollinearity.

\section{FDI in Poland, main stylised facts}

As have been mentioned, the nexus between FDI and trade (exports) is difficult to be predicted and the relation can be ambiguous. Depending on the variety of factors, FOEs can be more oriented towards the domestic market or can be strongly oriented towards foreign ones. What shall be stressed however, is the much higher share of FOEs in Poland's exports that in such categories as employment, investment outlays or manufacturing output (Table 3). FOEs account for roughly the half of Poland's exports and imports, while their contribution to capital formation is close to 21 per cent, and to employment is even lower. Poland obtained similar contribution of FOEs in exports as the Czech Republic (50.7 per cent), UK (48.7), Netherlands (46.0) and significantly higher as Germany (24.8), Denmark (29.9), Spain (36.6). Only in the case of Slovakia (74.8) and Romania (66.4) FOEs contribution was higher, according to the Eurostat data.

FOEs export performance differs in NUTS-2 regions, which reflects their competitiveness, attractiveness and structural characteristics. Moreover, depending on the character of the activity of FOEs established in particular regions, their extensive and intensive margins can be different. Regions differ in many aspects, GDP structure, unemployment, business demographics, competitiveness and investment attractiveness. An important aspect of these differences is the contribution of FOEs to exports of particular regions, and to SS-compliant exports in particular.

Table 3. The mean contribution of FOEs to regional economies in Poland (in per cent) (source: Own compilation)

\begin{tabular}{|l|c|c|c|c|c|c|c|c|c|c|c|c|}
\hline & 2004 & 2005 & 2006 & 2007 & 2008 & 2009 & 2010 & 2011 & 2012 & 2013 & 2014 & 2015 \\
\hline Exports & 49.9 & 50.8 & 50.4 & 52.1 & 52.9 & 54.5 & 54.7 & 53.3 & 51.5 & 51.6 & 51.9 & 52.1 \\
\hline Imports & 50.6 & 51.8 & 51.2 & 51.3 & 50.4 & 54.1 & 54.4 & 54.3 & 53.4 & 53.7 & 53.7 & 55.4 \\
\hline $\begin{array}{l}\text { Capital } \\
\text { formation }\end{array}$ & 25.6 & 28.0 & 28.9 & 27.4 & 25.5 & 21.2 & 19.3 & 20.6 & 22.4 & 22.5 & 20.9 & 21.1 \\
\hline Employment & 6.6 & 6.8 & 7.3 & 7.7 & 7.8 & 7.3 & 7.7 & 7.9 & 7.9 & 8.3 & 8.6 & 8.9 \\
\hline
\end{tabular}

Figure 1 depicts the contribution of FOEs to exports in 2015 for NUTS-2 regions. It ranges from 13 to 70 per cent. Even stronger differences are seen for FOEs share in SScompliant exports (from 3.6 to 83 per cent), presented on Figure 2. Regions located closer to the south-western border have the highest FOEs' contribution to exports per se and SScompliant exports. It reflects the gravity forces and the role of the EU's market (German in particular). Due to the idiosyncratic factors, even particular eastern regions of Poland witness high contribution of FOEs in SS-compliant exports. These are often highly specialised and high-tech clusters of FDI, located in regions with low economic base. The detailed statistics for particular regions are shown in Table 4, where i.a. SS-compliant exports are presented. 


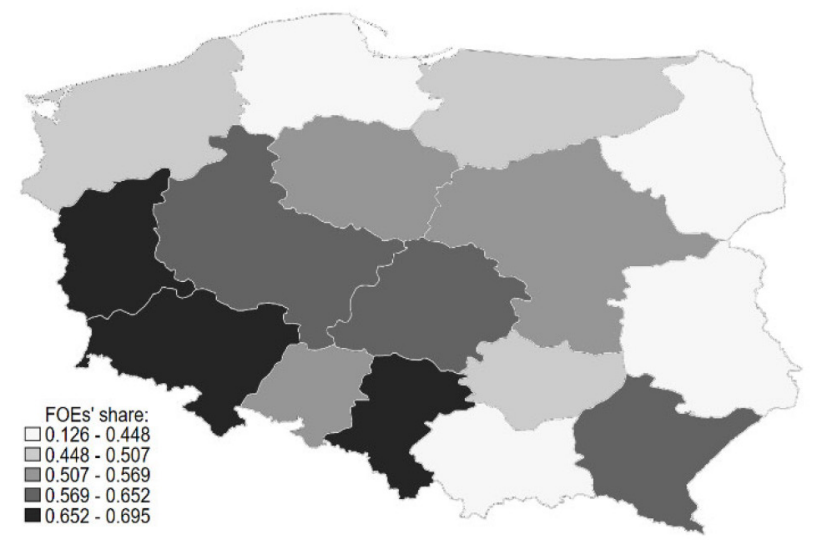

Figure 1. FOEs contribution to regional exports in 2015

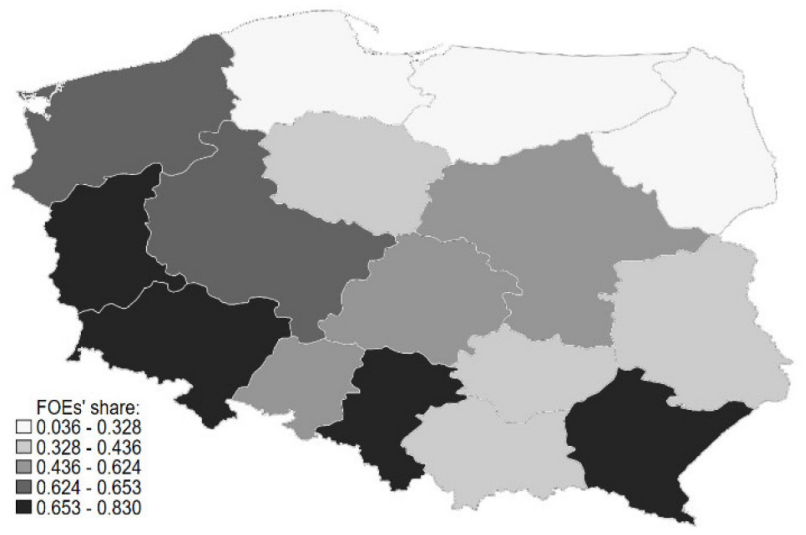

Figure 2. FOEs contribution to regional SS-compliant exports in 2015 (source: Own compilation)

A novelty brought by the research is the set of indices proposed and calculated in order to capture the position of FOEs vs. non-FOEs in exports. They are presented in Table 5, as averages for 16 NUTS-2 regions. In case of FOEs exports, there is lower number of products with revealed comparative advantages (based on the weighted RCA indices), compared to indigenous firms. This applies to both variants of RCA indices: wrca2 indicating the number of products for which the index is higher than 2, and wrca5, higher than 5 respectively.

Similar situation is observed for indices based on shares. For instance, sh_wrca2 index depicts the share of products, with WRCA above 2 for a particular region, in exports. These indices take higher values for non-FOEs. The obtained results show that in case of non-FOEs' exports, the share of products in which a region has comparative advantages, is higher than for FOEs. It however does not inform us yet about the contribution of FOEs to SS. FOEs exports shows higher product concentration and specialisation vs. non-FOEs, which is proved by hhi_ex and ksi_ex indices. 
Table 4. Share of FOEs in Poland's NUTS-2 regions exports and imports as well as in SS-compliant exports in 2015 (source: Own compilation)

\begin{tabular}{|c|c|c|c|c|c|c|}
\hline Region & Exports & Imports & $\begin{array}{c}\text { High-tech } \\
\text { exports }\end{array}$ & $\begin{array}{c}\text { SS- } \\
\text { compliant } \\
\text { exports }\end{array}$ & $\begin{array}{c}\text { SS- } \\
\text { compliant } \\
\text { agricultural } \\
\text { exports }\end{array}$ & $\begin{array}{c}\text { SS- } \\
\text { compliant } \\
\text { high-tech } \\
\text { exports }\end{array}$ \\
\hline PL11 & 0.652 & 0.689 & 0.448 & 0.624 & 0.336 & 0.212 \\
\hline PL12 & 0.508 & 0.632 & 0.422 & 0.558 & 0.412 & 0.485 \\
\hline PL21 & 0.445 & 0.538 & 0.381 & 0.426 & 0.055 & 0.627 \\
\hline PL22 & 0.695 & 0.674 & 0.731 & 0.653 & 0.000 & 0.667 \\
\hline PL31 & 0.448 & 0.442 & 0.595 & 0.328 & 0.204 & 0.070 \\
\hline PL32 & 0.630 & 0.631 & 0.928 & 0.830 & 0.075 & 0.992 \\
\hline PL33 & 0.449 & 0.430 & 0.712 & 0.436 & 0.006 & 0.168 \\
\hline PL34 & 0.126 & 0.178 & 0.126 & 0.055 & 0.049 & 0.871 \\
\hline PL41 & 0.626 & 0.743 & 0.806 & 0.646 & 0.293 & 0.927 \\
\hline PL42 & 0.507 & 0.522 & 0.693 & 0.648 & 0.000 & 0.098 \\
\hline PL43 & 0.681 & 0.727 & 0.943 & 0.696 & 0.218 & 0.416 \\
\hline PL51 & 0.665 & 0.741 & 0.683 & 0.678 & 0.171 & 0.661 \\
\hline PL52 & 0.569 & 0.648 & 0.900 & 0.487 & 0.550 & 0.272 \\
\hline PL61 & 0.518 & 0.458 & 0.659 & 0.422 & 0.191 & 0.022 \\
\hline PL62 & 0.480 & 0.507 & 0.064 & 0.118 & 0.060 & 0.000 \\
\hline PL63 & 0.337 & 0.306 & 0.900 & 0.036 & 0.000 & 0.512 \\
\hline
\end{tabular}

Table 5. Selected differences of NUTS-2 regions exports by the type of exporter (FOE vs non-FOE) (source: Own compilation)

\begin{tabular}{|c|c|c|c|c|c|c|c|}
\hline Indices & Description & Origin & 2004 & 2008 & 2010 & 2013 & 2015 \\
\hline \multirow{2}{*}{ wrca2 } & \multirow{2}{*}{$\begin{array}{l}\text { Mean no. of } 4 \text {-digit product } \\
\text { groups in exports with WRCA }>2\end{array}$} & non-FOEs & 78.9 & 79.4 & 79.3 & 85.9 & 84.0 \\
\hline & & FOEs & 59.6 & 61.4 & 61.1 & 65.0 & 65.7 \\
\hline \multirow{2}{*}{ wrca5 } & \multirow{2}{*}{$\begin{array}{l}\text { Mean no. of } 4 \text {-digit product } \\
\text { groups in exports with WRCA }>5\end{array}$} & non-FOEs & 38.6 & 38.2 & 38.3 & 39.9 & 38.9 \\
\hline & & FOEs & 31.8 & 32.0 & 31.7 & 33.7 & 32.6 \\
\hline \multirow{2}{*}{$\begin{array}{l}\mathrm{sh}_{-} \\
\text {wrca2 }\end{array}$} & \multirow{2}{*}{$\begin{array}{l}\text { Mean share of } 4 \text {-digit product } \\
\text { groups in exports with WRCA }>2\end{array}$} & non-FOEs & 0.157 & 0.163 & 0.159 & 0.165 & 0.164 \\
\hline & & FOEs & 0.083 & 0.084 & 0.094 & 0.095 & 0.095 \\
\hline \multirow{2}{*}{$\begin{array}{l}\text { sh_- } \\
\text { wrca5 }\end{array}$} & \multirow{2}{*}{$\begin{array}{l}\text { Mean share of } 4 \text {-digit product } \\
\text { groups in exports with WRCA }>5\end{array}$} & non-FOEs & 0.073 & 0.077 & 0.067 & 0.074 & 0.079 \\
\hline & & FOEs & 0.046 & 0.042 & 0.048 & 0.048 & 0.048 \\
\hline \multirow{2}{*}{ hhi_ex } & \multirow{2}{*}{$\begin{array}{l}\text { Mean Herfindahl-Hirschman } \\
\text { Index of total exports }\end{array}$} & non-FOEs & 0.067 & 0.052 & 0.052 & 0.045 & 0.047 \\
\hline & & FOEs & 0.086 & 0.085 & 0.084 & 0.072 & 0.073 \\
\hline \multirow{2}{*}{ ksi_ex } & \multirow{2}{*}{$\begin{array}{l}\text { Mean Krugman Specialisation } \\
\text { Index for exports }\end{array}$} & non-FOEs & 1.248 & 1.227 & 1.249 & 1.202 & 1.176 \\
\hline & & FOEs & 1.412 & 1.364 & 1.372 & 1.356 & 1.347 \\
\hline \multirow{2}{*}{$\begin{array}{l}\text { hhi_ } \\
\text { smart }\end{array}$} & \multirow{2}{*}{$\begin{array}{l}\text { Mean Herfindahl-Hirschman } \\
\text { Index of exports compliant with } \\
\text { SS }\end{array}$} & non-FOEs & 0.114 & 0.094 & 0.090 & 0.079 & 0.083 \\
\hline & & FOEs & 0.155 & 0.125 & 0.135 & 0.116 & 0.127 \\
\hline
\end{tabular}


End of Table 5

\begin{tabular}{|c|c|c|c|c|c|c|c|}
\hline Indices & Description & Origin & 2004 & 2008 & 2010 & 2013 & 2015 \\
\hline \multirow{2}{*}{$\begin{array}{l}\text { hhi_ } \\
\text { nosmart }\end{array}$} & \multirow{2}{*}{$\begin{array}{l}\text { Mean Herfindahl-Hirschman } \\
\text { Index of exports inconsistent } \\
\text { with SS }\end{array}$} & non-FOEs & 0.074 & 0.071 & 0.078 & 0.059 & 0.057 \\
\hline & & FOEs & 0.134 & 0.134 & 0.127 & 0.119 & 0.115 \\
\hline \multirow{2}{*}{$\begin{array}{l}\text { ksi_ } \\
\text { smart }\end{array}$} & \multirow{2}{*}{$\begin{array}{l}\text { Mean Krugman Specialisation } \\
\text { Index of exports compliant with } \\
\text { SS }\end{array}$} & non-FOEs & 1.086 & 1.086 & 1.085 & 1.025 & 1.009 \\
\hline & & FOEs & 1.360 & 1.315 & 1.277 & 1.251 & 1.258 \\
\hline \multirow{2}{*}{$\begin{array}{l}\text { ksi__ } \\
\text { nosmart }\end{array}$} & \multirow{2}{*}{$\begin{array}{l}\text { Mean Krugman Specialisation } \\
\text { Index of exports inconsistent } \\
\text { with SS }\end{array}$} & non-FOEs & 1.258 & 1.251 & 1.281 & 1.240 & 1.218 \\
\hline & & FOEs & 1.385 & 1.350 & 1.379 & 1.362 & 1.339 \\
\hline \multirow{2}{*}{$\begin{array}{l}\text { sh_ } \\
\text { smart }\end{array}$} & \multirow{2}{*}{$\begin{array}{l}\text { Mean share of exports in line } \\
\text { with SS }\end{array}$} & non-FOEs & 0.472 & 0.500 & 0.517 & 0.529 & 0.517 \\
\hline & & FOEs & 0.401 & 0.396 & 0.414 & 0.412 & 0.416 \\
\hline \multirow{2}{*}{$\begin{array}{l}\text { sh_ } \\
\text { smart_ } \\
\text { agri }\end{array}$} & \multirow{2}{*}{$\begin{array}{l}\text { Mean share of agricultural } \\
\text { exports in line with SS }\end{array}$} & non-FOEs & 0.083 & 0.092 & 0.106 & 0.108 & 0.113 \\
\hline & & FOEs & 0.022 & 0.022 & 0.027 & 0.032 & 0.029 \\
\hline \multirow{2}{*}{$\begin{array}{l}\text { sh_ } \\
\text { smart_ } \\
\text { ht }\end{array}$} & \multirow{2}{*}{$\begin{array}{l}\text { Mean share of high-tech exports } \\
\text { in line with SS }\end{array}$} & non-FOEs & 0.025 & 0.035 & 0.044 & 0.072 & 0.068 \\
\hline & & FOEs & 0.035 & 0.054 & 0.072 & 0.083 & 0.091 \\
\hline \multirow{2}{*}{ sh_ht } & \multirow{2}{*}{ Mean share of high-tech exports } & non-FOEs & 0.040 & 0.047 & 0.045 & 0.060 & 0.059 \\
\hline & & FOEs & 0.088 & 0.101 & 0.110 & 0.113 & 0.120 \\
\hline
\end{tabular}

In the next step, indices based on shares have been used. SS-compliant exports share (sh_smart) is higher in case of non-FOEs, which is in line with the obtained results based on RCA indices. The difference is even higher for agricultural products (sh_smart_agri). In case of high-tech products, the reversed situation is observed. These are FOEs that reveal higher share of SS-compliant products in their total exports, which stems from the fact that for total FOEs exports, the share of high-tech products is higher: 12 per cent in 2015 compared to 5.9 per cent for non-FOEs.

The presented data shall be however treated with caution, as these are the averages for 16 regions. More detailed and comprehensive inquiry with the use of econometric modelling is required. The estimations were computed for two dependent variables, each time using a similar set of explanatory variables. At the first stage, a reference point is estimated with (log) exports, whereas in the second step, the role of FOEs in $(\log )$ exports in line with regional smart specialisations is revealed.

\section{Results}

Smart specialisation as such, leads to the improved export performance, which supports the currently adopted policy approach. Firms whose activity falls into SS, are more conscious about the global challenges. They are highly motivated towards acquiring new competences and qualifications, which in the end - leads to productivity improvements, positively effecting extensive margin of exports. Brodzicki and Umiński (2017b) have shown that for firms within SS in Pomorskie, the personnel hiring prospects are three times more intensive, than 
for firms outside SS. In the long run it also shall impact exports, as size has been proved as a factor of export success (Mayer \& Ottaviano, 2008). However, it may lead to spatial sorting (Baldwin \& Okubo, 2005). The highest productivity firms move to the core regions, while lowest productivity firms move to the periphery. Further differentiation of firms and regions maybe induced by learning by exporting effects, however the literature does not provide conclusive evidence thereof (Damijan \& Kostevc, 2006; Loecker, 2013; Silva et al., 2012). There are also other factors directly impacting exports' results. As it was shown by Brodzicki and Umiński (2017a), Nazarczuk and Umiński (2018) these are: path-dependency, metropolitan status of a region, location of special economic zones.

The results of the econometric inquiry convey positive role of FOEs on exports (lex), signalling their importance in the internationalisation of Poland's regions. Columns 1-3 (Table 6) acknowledge the positive role of FOEs thereof, introduced into the model in various ways: the share FOEs in employment (sh_em_foe), ratio of FOE in relation to $1 \mathrm{k}$ registered entities (sh_foe_lkent), and finally the share of FOEs' exports in total regional exports (sh_foe_ex). The highest magnitudes of their influence are observed within the share of FOEs in regional exports and employment. Their nonnegative contribution is tested against other factors, such as: access to sea (sea), share of industry in employment (sh_emp_2), share of population aged 25-64 with tertiary education $(h c)$.

The introduction of other variables related to the operation of FOEs in the area of foreign trade, but consistent with SSs in total or sector-specific (columns 4-6), underlines their positive contribution to regional exports. The obtained results are in line with expectations, proving the advantages of FOEs over the indigenous firms, in exports performance. Exporting activity is for "a happy few". As it was shown by Ciołek and Brodzicki (2016), there is a strong impact of FO on export activity. The probability of exporting is $300 \%$ higher for FOEs, than for wholly Polish-owned firms. Hagemejer and Tyrowicz (2012) show that in the case of export intensity, the majority of the differential between the indigenous companies and FOEs is attributable to selection effects: MNEs choose export-oriented companies and sectors. According to Gajewski and Tchorek (2017), the factors of export success assessed at firm level, differ regionally. Export performance in the (less developed) eastern part of Poland benefits from family ties in business, non-price competitiveness and product innovations, while it is the western part of Poland, in which FO is the crucial factor of international competitiveness. FOEs in Poland reveal superiority over the indigenous firms in terms of productivity. Productivity as such - in line with heterogeneity concept (Melitz \& Redding, 2014) - positively affects export extensive margin.

The obtained findings acknowledge the positive role of FOEs in regional exports, what leads to the approval of H1. Particularly interesting is the link between the contribution of FOEs to regional SS and the value of exports (logged), which can be seen as a measure of regional internationalisation and competitiveness, bringing important policy implications. The findings also indicate the beneficial role of FOEs export compliant with SS in regional exports. However, their contribution thereof was smaller than in the case of total exports. Yet, in two cases of sectoral-trimmed exports (in line with SS), the effects of FOEs were heterogeneous (positive in the case of high-tech exports and non-significant for agricultural products). Obviously, the issue needs further investigation as it can lead to unequal role of FOEs in export-related SSs. 
Table 6. The contribution of FOEs to regional exports (source: own estimates in Stata 14.2. Panelcorrected standard errors in parentheses)

\begin{tabular}{|c|c|c|c|c|c|c|}
\hline \multirow{2}{*}{ Variables } & (1) & (2) & (3) & (4) & (5) & (6) \\
\hline & lex & lex & lex & lex & lex & lex \\
\hline \multirow{2}{*}{ sea } & $0.131^{* * *}$ & 0.00358 & $0.368^{\star * *}$ & $0.383^{* * *}$ & $0.264^{\star * *}$ & $0.178^{\star * *}$ \\
\hline & $(0.0213)$ & $(0.0251)$ & $(0.0459)$ & $(0.0299)$ & $(0.0585)$ & $(0.0391)$ \\
\hline \multirow{2}{*}{ sh_emp_2 } & $0.0715^{\star \star \star}$ & $0.0847^{\star * *}$ & $0.0614^{\star * *}$ & $0.0817^{\star \star \star}$ & $0.0963^{\star \star *}$ & $0.103^{\star * *}$ \\
\hline & $(0.00453)$ & $(0.00641)$ & $(0.00814)$ & $(0.00834)$ & $(0.00785)$ & $(0.00879)$ \\
\hline \multirow{2}{*}{ hc } & $0.0587^{\star * *}$ & $0.0714^{* * *}$ & $0.111^{\star * *}$ & $0.109^{* * *}$ & $0.109^{\star * *}$ & $0.115^{\text {}}$ \\
\hline & $(0.00722)$ & $(0.0112)$ & $(0.0149)$ & $(0.0148)$ & $(0.0151)$ & $(0.0173)$ \\
\hline \multirow{2}{*}{ sh_emp_foe } & $9.921^{* * *}$ & & & & & \\
\hline & $(0.465)$ & & & & & \\
\hline \multirow{2}{*}{ sh_foe_lkent } & & $0.153^{* * *}$ & & & & \\
\hline & & $(0.00944)$ & & & & \\
\hline \multirow{2}{*}{ sh_foe_ex } & & & $2.438^{\star * *}$ & & & \\
\hline & & & $(0.146)$ & & & \\
\hline \multirow{2}{*}{$\begin{array}{l}\text { sh_foe_ } \\
\text { smart }\end{array}$} & & & & $1.270^{\star \star \star *}$ & & \\
\hline & & & & $(0.0875)$ & & \\
\hline \multirow{2}{*}{$\begin{array}{l}\text { sh_foe_- } \\
\text { smart_ht }\end{array}$} & & & & & $0.611^{* * *}$ & \\
\hline & & & & & $(0.0651)$ & \\
\hline \multirow{2}{*}{$\begin{array}{l}\text { sh_foe_- } \\
\text { smart_agri }\end{array}$} & & & & & & 0.135 \\
\hline & & & & & & $(0.128)$ \\
\hline \multirow{2}{*}{ Constant } & $17.90^{\star * *}$ & $17.39^{* * *}$ & $16.68^{\star * *}$ & $16.76^{* * *}$ & $16.66^{* * *}$ & $16.59^{\star * *}$ \\
\hline & $(0.242)$ & $(0.362)$ & $(0.500)$ & $(0.506)$ & $(0.525)$ & $(0.584)$ \\
\hline Observations & 192 & 192 & 192 & 192 & 192 & 192 \\
\hline R-squared & 0.755 & 0.662 & 0.602 & 0.593 & 0.570 & 0.520 \\
\hline $\begin{array}{l}\text { Number of } \\
\text { regions }\end{array}$ & 16 & 16 & 16 & 16 & 16 & 16 \\
\hline $\mathrm{Chi}^{2}$ & 2343 & 2039 & 726.4 & 1683 & 331.4 & 328.5 \\
\hline
\end{tabular}

${ }^{* * *} \mathrm{p}<0.01,{ }^{* *} \mathrm{p}<0.05,{ }^{*} \mathrm{p}<0.1$.

Columns 1-6 (Table 7) present the estimation results for the (logged) value of exports consistent with SSs with the use of similar empirical framework. The noticed differences in baseline scenarios, concern the role of access to sea, which coefficient is negative or insignificant, in most of estimations. It reflects lower than the mean value of SS compliant exports in regions with the access to sea, as well as can be driven by specific location of industry or regional composition of exports in Poland. The southern Poland's regions attract specific type of investors, including automobile industry, resulting in a more cooperative form of exports (also due to a higher role of intra-industry trade) in comparison to a more distant trade in longshore regions. 
Table 7. The contribution of FOEs to regional exports compliant with smart specialisations (source: own estimates in Stata 14.2. Panel-corrected standard errors in parentheses)

\begin{tabular}{|c|c|c|c|c|c|c|}
\hline \multirow{2}{*}{ Variables } & (1) & (2) & (3) & (4) & (5) & (6) \\
\hline & lsmart_ex & lsmart_ex & lsmart_ex & lsmart_ex & lsmart_ex & lsmart_ex \\
\hline \multirow{2}{*}{ sea } & $-0.446^{* * *}$ & $-0.602^{* * *}$ & $-0.262^{\star * *}$ & $-0.259^{* * *}$ & $-0.279^{\star * *}$ & -0.0747 \\
\hline & $(0.0336)$ & $(0.0389)$ & $(0.0533)$ & $(0.0434)$ & $(0.0792)$ & $(0.0484)$ \\
\hline \multirow{2}{*}{ sh_emp_2 } & $0.0387^{\star * *}$ & $0.0536^{* * *}$ & $0.0457^{* * *}$ & $0.0614^{* * *}$ & $0.0675^{\star * \star}$ & $0.0716^{* * *}$ \\
\hline & $(0.00396)$ & $(0.00578)$ & $(0.00899)$ & $(0.00893)$ & $(0.00764)$ & $(0.00761)$ \\
\hline \multirow{2}{*}{ hc } & $0.0635^{* * *}$ & $0.0768^{* * *}$ & $0.127^{\star \star \star}$ & $0.126^{* \star *}$ & $0.122^{* * *}$ & $0.126^{\star * \star}$ \\
\hline & $(0.00557)$ & $(0.00913)$ & $(0.0157)$ & $(0.0158)$ & $(0.0147)$ & $(0.0153)$ \\
\hline \multirow{2}{*}{ sh_emp_foe } & $11.74^{\star * *}$ & & & & & \\
\hline & $(0.543)$ & & & & & \\
\hline \multirow{2}{*}{ sh_foe_1kent } & & $0.187^{\star * *}$ & & & & \\
\hline & & $(0.00931)$ & & & & \\
\hline \multirow{2}{*}{ sh_foe_ex } & & & $1.788^{\star * *}$ & & & \\
\hline & & & $(0.161)$ & & & \\
\hline \multirow{2}{*}{$\begin{array}{l}\text { sh_foe_ } \\
\text { smart }\end{array}$} & & & & $0.888^{\star * *}$ & & \\
\hline & & & & $(0.0982)$ & & \\
\hline \multirow{2}{*}{$\begin{array}{l}\text { sh_foe_- } \\
\text { smart_ht }\end{array}$} & & & & & $0.771^{\star * *}$ & \\
\hline & & & & & $(0.111)$ & \\
\hline \multirow{2}{*}{$\begin{array}{l}\text { sh_foe_- } \\
\text { smart_agri }\end{array}$} & & & & & & $1.809^{* * *}$ \\
\hline & & & & & & $(0.150)$ \\
\hline \multirow{2}{*}{ Constant } & $17.82^{\star * *}$ & $17.25^{\star * *}$ & $16.35^{\star * *}$ & $16.40^{\star * *}$ & $16.36^{\star * *}$ & $16.20^{* * *}$ \\
\hline & $(0.191)$ & $(0.295)$ & $(0.520)$ & $(0.530)$ & $(0.499)$ & $(0.508)$ \\
\hline Observations & 192 & 192 & 192 & 192 & 192 & 192 \\
\hline R-squared & 0.644 & 0.554 & 0.426 & 0.420 & 0.453 & 0.462 \\
\hline $\begin{array}{l}\text { Number of } \\
\text { regions }\end{array}$ & 16 & 16 & 16 & 16 & 16 & 16 \\
\hline $\mathrm{Chi}^{2}$ & 1426 & 2129 & 484.2 & 1170 & 172.3 & 357.6 \\
\hline
\end{tabular}

${ }^{* * *} \mathrm{p}<0.01,{ }^{* *} \mathrm{p}<0.05,{ }^{*} \mathrm{p}<0.1$.

Among other factors, the role of FOEs in regional economies is positive, when proxied by the share of FOEs in employment ( $s h_{-} e m p \_f o e$ ), the ratio of FOEs to registered $1 \mathrm{k}$ entities (sh_foe_lkent) or share of FOEs in exports (sh_foe_ex). The latter was however of a lesser magnitude than in the Table 6 (when log exports was at a stake), what may imply to some extent divergent structure of exports falling into regional SSs and products exported by FOEs. It indicates different businesses aims and strategies, that drive foreign entities, which do not always have to conform to established regional comparative advantages or smart strategies.

The issue is also noticed when sectoral composition of SS exports is taken into account. FOEs contribute significantly to the value of SS compliant exports (sh_foe_smart), agricultural ones (sh_foe_smart_agri) as well as high-tech ones (sh_foe_smart_ht), but their magni- 
tudes differ substantially (Columns 4-6, Table 7). Therefore, their contribution to SS may be seen as sector-specific. The highest - in the case of agricultural products - may be a result of a relatively high importance of FDI in food and agricultural products. On the other hand, the lowest magnitude may be an effect of insufficient embeddedness of FOEs in regional economies and the regional structure of the established regional SS in the case of high-tech products. However, high-tech products appear in regional SS rather rarely, and their contribution to the total composition of exports in line with SS is high (above 10\%) only in the case of three regions (Podkarpackie, Slaskie, Mazowieckie), whereas in majority of them is tiny or non-existent.

The obtained findings confirm the $\mathrm{H} 2$, implying the positive role of FOEs in generating SS-related exports. Owing to the broader scope of their operation than established regional SS, more actions undertaken towards further inclusion of these entities in regional SS or regional economies are needed. The other possibility stems from the operation of sectorselective policy attracting investors to come to the region to set their establishments. With respect to human capital, demographic features should be noticed. Brodzicki and Umiński (2017b) have identified the lack of human capital as a main obstacle declared by firms, which activity is falling into SSs. They require highly qualified personnel to develop. However, due to demographic changes these personnel become less available. This raises the issue of labour-to-capital replacement. Thus, the incoming FDI represent the important capital infusion, enabling the development of SS firms.

\section{Conclusions}

Given the insufficient empirical contributions on the effects of smart specialisations in the area of foreign trade, the study aimed at identification of the FOEs' role in regional SSs through exports. The paper's main goal was to identify: (i) the character, extent and conditions to which FOEs contribute to regional SSs, (ii) the role of FOEs in emerging new product specialisations in exports, (iii) the FOEs contribution to regions' exporting comparative advantages. Its' novelty arises from: (i) providing empirical verification of one of the aspects of SS strategy which is exports and thus establishing more comprehensive insight into the evaluation of SS, (ii) depicting the role of FOEs in generating SS-compliant exports, (iii) proposing a set of comprehensive measures to be used is the extended empirical evaluation of SS consequences in the sphere of international trade. To the knowledge of the authors it is the first approach to investigate the role of FOEs in SS-compliant regional exports.

An extended empirical framework to the research problem that can be utilized in other studies has been proposed. It's based on the compilation of trade data with regional smart specialisations, enabling to differentiate between SS-compliant and non-SS-compliant exports, coming from domestic and foreign-owned entities separately. In particular the following indices have been used: product-specific weighted RCA, HHI, Krugman Specialisation Index, share of FOE in exports, share of FOE in exports compliant with regional SSs (also sectoral aggregated).

The results of the estimations have acknowledged the positive role of FOEs in boosting regional exports as well as in creating SS-compliant exports. However, the magnitude of 
the effect was unequal. One percentage growth in the share of exports generated by FOEs transferred to 2.4 fold increase in total regions' exports, whereas only in 1.8 fold increase in exports compliant with regional SS. Obviously, not all FOEs conform their exports to regional SS.

From the point of view of the effectiveness of the regional policy, and especially its implementation which are smart specialisations, it is important to emphasize the important role played by foreign investors in creating exports. This can be seen in relation to exports as such and exports in line with SS. For regional authorities, in particular for agencies responsible for attracting investments and promoting exports, this is a clear signal on how to design regional policy that focuses on the concept of smart specialisation. According to our research and experience, the activity of companies with foreign capital is not sufficiently taken into account in the preparation and implementation of the SS. Regional authorities should therefore approach this issue in a more comprehensive way, as FDI contributes to the increase in the volume of regional exports and exports compatible with the SS.

The obtained findings stress the necessity of FOEs' embeddedness in regional economies, which should be enhanced, i.a. through increases in the number and intensity of relations with local/regional setting. Secondly, FOEs' operation should be more seriously concerned in the choices of regional SSs, as it in many cases encompasses broader product specialisations. Actions undertaken towards further inclusion of these entities in regional SS or regional economies are needed that could eventually materialise in new or more intense regional comparative advantages. The issue is worthy underlining especially in sectoral-selected branches of economy, which can have the greatest impact on regions' economies (e.g. high-tech, were FOEs can introduce positive amendments). FOEs play a variety of functions in an economy, being a dynamic factor affecting changes in regions. Thus, FOEs' operation should be to a broader extent incorporated into regional strategic documents, including regional SSs as they may lead to positive contribution thereof (i.e. enhance existing regional competitive advantages or create new domains). SS strategy should also be internationalised in a "smart" way, which means the most effective usage of advantages possessed by FOEs and incorporating them into regional development. Lastly, locational choices of FOEs are in many cases driven by different motives, than of indigenous entities. Thus, any policy can have a limited effect on multinational entities, given their dominant role in the global economy. Any activity aimed at attraction of FOEs must be a far reaching and dynamic process in which not only the ongoing SS and comparative advantages are taken into account. The dynamic market changes shall be observed and followed. The superstar firms of the future shall be nurtured. SSs have been formulated according to the sectoral formula. The horizontal approach, related to the export promotion, is neglected. Exports could be promoted through reduction of trade costs, that is possible through agglomeration processes that allow learning, sharing and matching.

Also, structural features deserve attention. The effects of SS do not limit to high-tech branches of manufacturing, but are also visible in more traditional sectors, like agri-food processing. Depending on the level of regions' economic and technological development, their smart specialisations can follow different paths. In the case of less developed regions, they are frequently based on low-tech manufacturing, including the in which a region has a solid comparative advantage. 
The research presented subscribes into the literature on the consequences of FDI inflow (and presence) in a region's economy, in which sectoral heterogeneity of FOEs is particularly discussed. Basically, from the regional policy perspective, FDI represent external resources attracted to a region with the purpose to improve its economic situation, incl. exports. Once regions have formulated their SS strategies, one can assume that their priorities well reflect regional strengths and the revealed comparative advantages. Thus, a good test for the role played by FOEs is their contribution to region's exports development, in line with SS priorities. FDI sometimes are described as footloose capital, moving from one place to another, reacting to changes in labour costs, regulatory climate and prone to changing strategic goals of the mother company. The real challenge is "rooting" FOEs in a region through creation of dense relations between foreign investors and the regional economy and its main actors (other companies, universities, regional authorities). The efficiency of this rooting can be assessed on the grounds of FOEs contribution to the successful internationalisation of SS through exports.

National and regional agencies, involved in the process of FDI attraction, should put more attention to the sectoral compliance of incoming FDI with regional economy and established SSs. Successful exports achievements of firms established in SSs can be used as case studies and benchmarks for other companies, which may contribute to the spillover and learning effects, also through increasing the extensive margin of exports. As a result, it will assist SS's firms to keep with their global competitors. The positive spillover effects from FOEs presence can also stem from agglomeration processes, which facilitate exports.

The study suffers from a few limitations, mostly originating from data concerns. Firstly, due to unavailability of export data on trade in services, this sector is not taken into account in the study. Obviously, its role in exports is lowly, compared to manufacturing exports. However, in the case of particular regions (esp. agglomerated ones), its contribution may be significant. Secondly, the analysis has been restricted to exporting activity, not presenting the effects of FOEs' activity in other areas of the economy, like: employment, capital formation, etc. Exports, however, is a true validator of international competitiveness, analysed at different levels of data aggregation.

Given that relatively little is known about the nexus between SSs and the global market, it is recommended to establish a panel of firms for the purpose of evaluating the SS's effects on the exporting activity. Such a comprehensive dataset would constitute a basis for effective support and competitiveness improvements.

Furthermore, the ability of capturing sectoral dependencies of incoming FDI (given data constraints) with the existing regional economic structures might provide valuable implications for regional policy. Similarly, the heterogeneity of the origin of the investor may result in an uneven scale of observed effects, which may be also furtherly analysed, given the availability of the data. Another interesting venue of the research would be to show differences between entities with various share of foreign capital (entities fully owned by foreign capital vs. minority foreign ownership). Also, more in depth inquiry into the other forms of ownership could be provided (i.e. state, municipal, cooperative forms of ownership). Different management styles and effectiveness, combined with ownership advantages determine productivity, which translates into exports performance. Availability of firm-level data would 
enable to capture various margins of exports. Apart from exports, also other forms of internationalisation could be examined, as regards the consequences of SS schemes realisation. Lastly, in future studies, one may also include spatial dependencies among the regions, to better depict existing inter-regional relations. By providing such a research the authors hope that similar studies in other countries will emerge, which would start an interesting and fruitful discussion.

\section{Funding}

The paper is a part of the project entitled "Regional exporting activity. Assessment of determinants in light of contemporary foreign trade theory for Poland and Spain" supported by the National Science Centre of Poland under the grant no. 2015/19/B/HS4/01704.

\section{Author contributions}

Jarosław M. Nazarczuk (50 per cent), Stanisław Umiński (35 per cent), Tomasz Jurkiewicz (15 per cent).

\section{Disclosure statement}

The are no conflicts of interest.

\section{References}

Aitken, B., Hanson, G. H., \& Harrison, A. E. (1997). Spillovers, foreign investment, and export behavior. Journal of International Economics, 43(1-2), 103-132. https://doi.org/10.1016/S0022-1996(96)01464-X

Baldwin, R. E., \& Okubo, T. (2005). Heterogeneous firms, agglomeration and economic geography: Spatial selection and sorting. Journal of Economic Geography, 6(3), 323-346. https://doi.org/10.1093/jeg/lbi020

Baltagi, B. H., \& Li, Q. (1991). A joint test for serial correlation and random individual effects. Statistics \& Probability Letters, 11(3), 277-280. https://doi.org/10.1016/0167-7152(91)90156-1

Baltagi, B. H., \& Li, Q. (1995). Testing AR(1) against MA(1) disturbances in an error component model. Journal of Econometrics, 68(1), 133-151. https://doi.org/10.1016/0304-4076(94)01646-H

Beck, N., \& Katz, J. N. (1995). What to do (and not to do) with time-series cross-section data. American Political Science Review, 89(03), 634-647. https://doi.org/10.2307/2082979

Behrman, J. N. (1972). The role of international companies in Latin America: Autos and petrochemicals. Lexington Books. https://doi.org/10.1002/tie.5060140312

Brodzicki, T., \& Umiński, S. (2017a). A gravity panel data analysis of foreign trade by regions: The role of metropolises and history. Regional Studies, 11(1), 1-13. https://doi.org/10.1080/00343404.2017.1296123

Brodzicki, T., \& Umiński, S. (2017b). Zapotrzebowanie pracodawców na kompetencje pracowników w kontekście rozwoju społeczno-gospodarczego województwa pomorskiego. Pomorskie obserwatorium rynku pracy (grudzień), 1-113. 
Buckley, P. J., \& Ghauri, P. N. (2004). Globalisation, economic geography and the strategy of multinational enterprises. Journal of International Business Studies, 35(2), 81-98. https://doi.org/10.1057/palgrave.jibs.8400076

Cantwell, J., \& Iammarino, S. (2001). The technological relationships between indigenous firms and foreign-owned MNCs in the European regions.

Chang, S.-J., Chung, J., \& Jungbien Moon, J. (2013). When do foreign subsidiaries outperform local firms? Journal of International Business Studies, 44(8), 853-860. https://doi.org/10.1057/jibs.2013.35

Charles, D., Gross, F., \& Bachtler, J. (2012). Smart specialisation and cohesion policy. A strategy for all regions? IQ-Net Thematic Paper, 30(2), 1-51.

Charron, N., Dahlberg, S., Holmberg, S., Rothstein, B., Khomenko, A., \& Svensson, R. (2016). The quality of government EU regional dataset. Version September 2016. University of Gothenburg: The Quality of Government Institute. http://www.qog.pol.gu.se

Cieślik, A. (2016). Exports versus FDI in Smith-Motta framework. Equilibrium. Quarterly Journal of Economics and Economic Policy, 11(2), 189. https://doi.org/10.12775/EQUIL.2016.009

Ciołek, D., \& Brodzicki, T. (2016). Analysis of factors underpinning export activity of firms in Poland: Determinants of export activity of firms in Poland - the logit model. In K. Gawlikowska-Hueckel \& S. Umiński (Eds.), Analysis of the Polish foreign trade in the light of recent theoretical concepts (pp. 165-185). Scholar Publishing House.

Cordes, A., Gehrke, B., Rammer, C., Römisch, R., Schliessler, P., \& Wassmann, P. (2016). Identifying revealed comparative advantages in an EU regional context (Research Report 412). The Vienna Institute for International Economic Studies.

Coulombe, S. (2007). Globalization and regional disparity: A Canadian case study. Regional Studies, 41(1), 1-17. https://doi.org/10.1080/00343400601099698

Damijan, J. P., \& Kostevc, Č. (2006). Learning-by-exporting: Continuous productivity improvements or capacity utilization effects? Evidence from Slovenian Firms. Review of World Economics, 142(3), 599-614. https://doi.org/10.1007/s10290-006-0083-7

Dittfeld, M. (2017). Multinationality and performance: A context-specific analysis for German firms. Management International Review, 57(1), 1-35. https://doi.org/10.1007/s11575-016-0286-7

Dunning, J. H. (2003). Location and the multinational enterprise: A neglected factor? In T. Brewer, S. Young, \& S. Guisinger (Eds.), The new economic analysis of multinationals. Edward Elgar Publishing. https://doi.org/10.4337/9781843766995.00011

Dunning, J. H. (2009). Location and the multinational enterprise: John Dunning's thoughts on receiving the Journal of International Business Studies 2008 Decade Award. Journal of International Business Studies, 40(1), 20-34. https://doi.org/10.1057/jibs.2008.75

Dunning, J. H., \& Lundan, S. M. (2014). Multinational enterprises and the global economy (2 ${ }^{\text {nd }}$ ed.). Edward Elgar.

Dziemianowicz, W., Łukomska, J., \& Ambroziak, A. A. (2018). Location factors in foreign direct investment at the local level: The case of Poland. Regional Studies, 53(8), 1183-1192. https://doi.org/10.1080/00343404.2018.1530750

Estrin, S., Meyer, K. E., Wright, M., \& Foliano, F. (2008). Export propensity and intensity of subsidiaries in emerging economies. International Business Review, 17(5), 574-586. https://doi.org/10.1016/j.ibusrev.2008.04.002

Ethier, W. J. (1986). The multinational firm. Quarterly Journal of Economics, 101(4), 806-833. https://doi.org/10.2307/1884179

Felbermayr, G. J., \& Kohler, W. (2006). Exploring the intensive and extensive margins of world trade. Review of World Economics, 142(4), 642-674. https://doi.org/10.1007/s10290-006-0087-3 
Foray, D. (2014). Smart specialisation: Challenges and opportunities for regional innovation policies: Opportunities and challenges for regional innovation policy. Routledge. https://doi.org/10.4324/9781315773063

Foray, D. (2019). In response to "Six critical questions about smart spezialisation". European Planning Studies, 27(10), 2066-2078. https://doi.org/10.1080/09654313.2019.1664037

Foray, D., Goddard, J., Goenaga Beldarrain, X., Landabaso, M., McCann, P., Morgan, K., Nauwelaers, C., \& Ortega-Argilés, R. (2012). Guide to research and innovation strategies for smart specialisation (RIS 3). Regional policy. Luxembourg: Publications Office of the European Union.

Forsgren, M. (2008). Theories of the multinational firm: A multidimensional creature in the global economy. Edward Elgar.

Gajewski, P., \& Tchorek, G. (2017). What drives export performance of firms in Eastern and Western Poland? European Planning Studies, 25(12), 2250-2271. https://doi.org/10.1080/09654313.2017.1355890

Glickman, N. J., \& Woodward, D. P. (1989). The new competitors: How foreign investors are changing the the U.S. economy? Basic Books.

Hagemejer, J., \& Tyrowicz, J. (2012). Is the effect really so large? Firm-level evidence on the role of FDI in a transition economy. Economics of Transition, 20(2), 195-233.

https://doi.org/10.1111/j.1468-0351.2012.00433.x

Hassink, R., \& Gong, H. (2019). Six critical questions about smart specialization. European Planning Studies, 27(10), 2049-2065. https://doi.org/10.1080/09654313.2019.1650898

Helpman, E. (1984). A simple theory of international trade with multinational corporations. Journal of Political Economy, 92(3), 451-471. https://doi.org/10.1086/261236

Helpman, E., \& Krugman, P. R. (1985). Market structure and foreign trade: Increasing returns, imperfect competition, and the international economy. MIT Press.

Hymer, S. H. (1972). The multinational corporation and the law of uneven development. In J. N. Bhagwati (Ed.), Economics and world order from the 1970's to the 1990's ( $\left.1^{\text {st }} \mathrm{ed} ., \mathrm{pp} .113-140\right)$. Free Press; Collier Macmillan.

Iammarino, S., \& McCann, P. (2013). Multinationals and economic geography: Location, technology and innovation. Edward Elgar Pub. Ltd. https://doi.org/10.4337/9781781954799

Jensen, C. (2002). Foreign direct investment, industrial restructuring and the upgrading of Polish exports. Applied Economics, 34(2), 207-217. https://doi.org/10.1080/00036840010025641

Jurkiewicz, T., \& Umiński, S. (2016). Analysis of factors underpinning export activity of firms in Poland: An analysis of the survey results. In K. Gawlikowska-Hueckel \& S. Umiński (Eds.), Analysis of the Polish foreign trade in the light of recent theoretical concepts (pp. 151-165). Scholar Publishing House.

Krammer, S. M. S. (2017). Science, technology, and innovation for economic competitiveness: The role of smart specialization in less-developed countries. Technological Forecasting and Social Change, 123, 95-107. https://doi.org/10.1016/j.techfore.2017.06.028

Leichenko, R. M., \& Erickson, R. A. (1997). Foreign direct investment and state export performance. Journal of Regional Science, 37(2), 307-329. https://doi.org/10.1111/0022-4146.00056

Loecker, J. D. (2013). Detecting learning by exporting. American Economic Journal: Microeconomics, 5(3), 1-21. https://doi.org/10.1257/mic.5.3.1

Markusen, J. R. (1984). Multinational, multi-plant economies, and the gains from trade. Journal of International Economics, 16(3-4), 205-226. https://doi.org/10.1016/S0022-1996(84)80001-X

Mayer, T., \& Ottaviano, G. I. P. (2008). The happy few: The internationalisation of European firms. Intereconomics, 43(3), 135-148. https://doi.org/10.1007/s10272-008-0247-X 
McCann, P., \& Ortega-Argilés, R. (2013). Smart specialization, regional growth and applications to European Union Cohesion Policy. Regional Studies, 49(8), 1291-1302. https://doi.org/10.1080/00343404.2013.799769

McCann, P., \& Ortega-Argilés, R. (2016). Smart specialisation, entrepreneurship and SMEs: Issues and challenges for a results-oriented EU regional policy. Small Business Economics, 46(4), 537-552. https://doi.org/10.1007/s11187-016-9707-z

Melitz, M. J. (2003). The impact of trade on intra-industry reallocations and aggregate industry productivity. Econometrica, 71(6), 1695-1725. https://doi.org/10.1111/1468-0262.00467

Melitz, M. J., \& Redding, S. J. (2014). Heterogeneous firms and trade. In G. Copinath, E. Helpman, \& K. Rogoff (Eds.), Handbooks in economics. Handbook of international economics (Vol. 4, pp. 1-54). Amsterdam: North-Holland. https://doi.org/10.1016/B978-0-444-54314-1.00001-X

Ministry of Infrastructure and Development. (2014a). Eastern Poland operational programme 20142020. Warsaw.

Ministry of Infrastructure and Development. (2014b). Intelligent development operational programme. Warsaw.

Mudambi, R., Li, L., Ma, X., Makino, S., Qian, G., \& Boschma, R. (2018). Zoom in, zoom out: Geographic scale and multinational activity. Journal of International Business Studies, 49(8), 929-941. https://doi.org/10.1057/s41267-018-0158-4

Nazarczuk, J. M., \& Krajewska, A. (2018a). Local determinants of foreign direct investment in Poland: The role of relative distance. Equilibrium. Quarterly Journal of Economics and Economic Policy, 13(1), 73-88. https://doi.org/10.24136/eq.2018.004

Nazarczuk, J. M., \& Krajewska, A. (2018b). Spatial concentration of foreign owned entities in Poland. Geographia Polonica, 91(4), 413-426. https://doi.org/10.7163/GPol.0128

Nazarczuk, J. M., \& Umiński, S. (2018). The impact of special economic zones on export behaviour: Evidence from Polish firm-level data. E+M Ekonomie a Management, 21(3), 4-22. https://doi.org/10.15240/tul/001/2018-3-001

Nazarczuk, J. M., Umiński, S., \& Brodzicki, T. (2019). Determinants of the spatial distribution of exporters in regions: The role of ownership. The Annals of Regional Science. https://doi.org/10.1007/s00168-019-00947-6

Nazarczuk, J. M., Umiński, S., \& Gawlikowska-Hueckel, K. (2018). The role of specialisation in the export success of Polish counties in 2004-2015. Entrepreneurial Business and Economics Review, 6(2), 91-109. https://doi.org/10.15678/EBER.2018.060205

Nguyen, Q. T. K. (2017). Multinationality and performance literature: A Critical review and future research agenda. Management International Review, 57(3), 311-347. https://doi.org/10.1007/s11575-016-0290-y

OECD. (2013). Innovation-driven growth in regions: The role of smart specialisation (Technology and Industry Policy Papers).

Pesaran, M. H. (2004). General diagnostic tests for cross section dependence in panels. (Working paper). University of Cambridge. https://doi.org/10.17863/CAM.5113

Radosevic, S., \& Ciampi Stancova, K. (2018). Internationalising smart specialisation: Assessment and issues in the case of EU new member states. Journal of the Knowledge Economy, 9(1), 263-293. https://doi.org/10.1007/s13132-015-0339-3

Silva, A., Afonso, O., \& Africano, A. P. (2012). Learning-by-exporting: What we know and what we would like to know. The International Trade Journal, 26(3), 255-288. https://doi.org/10.1080/08853908.2012.682022

Sun, H. (2001). Foreign direct investment and regional export performance in China. Journal of Regional Science, 41(2), 317-336. https://doi.org/10.1111/0022-4146.00219 
Sun, H., \& Parikh, A. (2010). Exports, inward Foreign Direct Investment (FDI) and regional economic growth in China. Regional Studies, 35(3), 187-196. https://doi.org/10.1080/713693805

Tan, D., \& Meyer, K. E. (2011). Country-of-origin and industry FDI agglomeration of foreign investors in an emerging economy. Journal of International Business Studies, 42(4), 504-520. https://doi.org/10.1057/jibs.2011.4

Trippl, M., Zukauskaite, E., \& Healy, A. (2019). Shaping smart specialization: The role of place-specific factors in advanced, intermediate and less-developed European regions. Regional Studies, 35(4), 1-13. https://doi.org/10.1080/00343404.2019.1582763

Umiński, S. (2016). The regionalisation of commercial policy and of export-related analyses. In K. Gawlikowska-Hueckel \& S. Umiński (Eds.), Analysis of the Polish foreign trade in the light of recent theoretical concepts (pp. 212-232). Scholar Publishing House.

Uyarra, E., Marzocchi, C., \& Sorvik, J. (2018). How outward looking is smart specialisation? Rationales, drivers and barriers. European Planning Studies, 26(12), 2344-2363. https://doi.org/10.1080/09654313.2018.1529146

Varblane, U., \& Ziacik, T. L. (2000). The Impact of foreign direct investment on the export activities of Estonian firms. Journal of East-West Business, 5(1-2), 173-190.

https://doi.org/10.1300/J097v05n01_09 